\title{
A NEW PERSPECTIVE ON THE POTENTIAL OF ORGANIZATION'S DEVELOPMENT
}

\author{
Rafat Krupski \\ ${ }^{a}$ Częstochowa University of Technology, Faculty of Management, \\ Częstochowa, Poland, \\ e-mail: rkrupski@op.pl
}

\begin{abstract}
The aim of the article is to show that organization's potential can be differently described as only by results. The proposals concern using both the category of balance or unbalance and the concept of the chaos edge for describing organization's potential. The paper takes a closer look at strategic potential of organization, and tries to find explanation of development mechanisms in descriptive theories, such as: complexity theory, systems theory, cybernetics, and chaos theory. This is the main aim of this article. The most interesting aspect of identifying and creating strategic potential of organization are processes aimed at achieving the balance or unbalance. According to various theories or concepts these processes determine the direction of change for an enterprise, both in the context of external and internal factors. Acknowledging the internal ones to be mainly connected with resources, the paper describes ways of creating the potential of company's development in connection with the levels of balance within an organization. Another issue is determining the point of reference for the potential, namely the highest possible level of business effectiveness in a given internal and external context. The basis for theoretical considerations will be the complexity theory and the concept of the chaos edge.
\end{abstract}

Key words: potential of organization, chaos theory, edge of chaos

Paper type: Conceptual paper

\section{Preliminary questions}

Mechanisms of organization's development, questions about the reason why some enterprises develop, some other do not and some even cease to exist is an absorbing issue.

Undoubtedly about the potential of organization's development resources decide (internal resources and access to external resources, their scale, configuration and characteristic). However identification of interdependence between the given indications of expansion and the significance of different resources used to create them is, as Godziszewski notes, extremely difficult in theoretical considerations as well as in empirical studies (Stankiewicz, 2010: 27). According to the professor, an adequately high level of generalization of considerations can be a remedy together 
A NEW PERSPECTIVE ON THE POTENTIAL

Rafał Krupski with theoretical basis- the resources theory, according to which an enterprise is perceived as a configuration of resources conditioned by competitive advantage and actual results, which are indications of development (Stankiewicz 2010: $27-$ -28). Obłój however does not subscribe to this view. He points out that capabilities are more important than resources and instead of the following model: resourcescompetitive advantage-results he proposes an alternative model: resources-key business processes-results (Obłój, 2007), a model close to the concept of dynamic capabilities presented in Teece D.J., Pisano G., Shuen A., Dynamic Capabilities and Strategic Management (Teece, Pisano, Shuen, 1997). In another famous book B. de Witt and R. Meyer describe this issue from the perspective of the endogenous strategies content. (de Wit, Meyer, 2007). Nonetheless, resources themselves or resources with an operational system (processes, capabilities) undoubtedly constitute the potential of organization's development. In an excellent book - Pozytywny potencjat organizacji (2010) it's authors attempt to examine the causality between the resources exemplified mainly by the social capital and the actual results of an enterprise defining it's development. In the present article, which is not polemical with the above mentioned publication I will take a closer look at other aspects of potential, mainly strategic potential of organization, which do not refer directly to various behavioural concepts, but they find explanation of development mechanisms in descriptive theories, such as: complexity theory, systems theory, cybernetics, and chaos theory. This is the main aim of this article. I believe that the most interesting aspect of identifying and creating strategic potential of organization are processes aimed at achieving the balance or unbalance. According to various theories or concepts these processes determine the direction of change for an enterprise, both in the context of external and internal factors. Acknowledging the internal ones to be mainly connected with resources, I will describe ways of creating the potential of company's development in connection with the levels of balance within an organization. Another issue will be determining the point of reference for the potential, namely the highest possible level of business effectiveness in a given internal and external context. The basis for theoretical considerations will be the complexity theory and the concept of the chaos edge.

\section{Balance as an archetype of potential of organization}

There is a rationale behind measuring the potential through results (economic, financial ones) but it is important to identify whether the subject of consideration are actual business results or predictable business results. Possible difference between potential and actual results should become the subject of analyses and measures taken. The potential results should be close to or identical with the maximum possible results achievable in a given environment. The balance 
between an organization and it's environment seems perfect in this context. Let me now give you more explanation of this concept.

Balance between two business systems (business environments) is defined in different ways in different sciences. The most universal and precise is the definition offered by cybernetics, in which homeostasis constitutes the fundamental mechanism, which is the subject of examination. According to cybernetics, balance is a state of no ongoing changes to the structure of a system or to the environment the system is set in. Balance is an indication of a negative feedback or an indication of many other connections between various sub-systems that make up a system. Depending on the structure of a system, i.e. network of connections, it can have one or more points of balance reference (issue of stability of a system) (Mały słownik cybernetyczny: 381). In economics supplydemand balance is a fundamental paradigm, and in reference to economic growth it denotes it's balanced character.

However, aspects of organization's balance (referring not to a macro economy, on a global scale but micro economy) are not still precisely defined as it is quite difficult. The theory of games proposes the Nash equilibrium in which each player is assumed to know the equilibrium strategies of the other players. In Polish Academia the following scholars presented their views on the subject: Stabryła (Stabryła 2005), Lichtarski (Lichtarski 2008) and previously Koźminski, and Obłój (Koźmiński, Obłój, 1989). Koźmiński, and Obłój claim that balance is not an abstract state of an organization but can be used to define management. Management, in their view, consist in defining and redefining the criteria of balance and necessary conditions to reach it in material and social dimensions, external and internal as well as such interaction between the business sub-systems and business environments, which leads to restoring and sustaining the balance. (Koźmiński, Obłój, 1989: 128). In this view the fundamental mechanisms of management are negative feedbacks, leading to eliminating disturbances, suppressing balance fluctuations while at the same time accomplishing primary objective of the survival of organization.

As essential to balance business processes in an organization they acknowledged the following instruments: strategy, organization structure, corporate culture, and internal procedures to be used depending on kinds of business sub-systems of an organization (material, social) and organization orientation (external, internal). With reference to this interesting approach, if we recognize that it is possible to determine the potential of an organization by means of strategy, structure, corporate culture or procedures, the balance between them (structured by specific ratios) assumes the highest level of the potential.

Modern concepts of organization dynamism however deprecate the balance claiming this is unbalance that provokes development. Thus, the programmes of company's development should be unbalanced. Unbalancing, which is an
A NEW PERSPECTIVE ON THE POTENTIAL

Rafał Krupski 
A NEW PERSPECTIVE ON THE POTENTIAL

Rafał Krupski indication of ex ante assumed lack of organizational balance can be of various sources:

- $\quad$ excessively ambitious objectives stimulating the organization which are not balanced with company's potential. (as it is argued by C.K. Prahalad and V. Ramaswamy who describing the concept of strategy as stretch write "instead of searching for conformity between objectives and resources of the company the focus should be on grasping the essence of entrepreneurship by imitating the model of a just established company, with a view to provoking discrepancy between resources and aspirations. It can be achieved not through limiting the resources but through increasing the aspirations“") (Prahalad, Ramaswamy, 2005: 191),

- objectives unbalanced with traditionally implied internal material resources, with a view to getting access to external resources,

- objectives unbalanced with traditionally implied internal material resources, in the hope that the deficit will be covered with immaterial resources, which are difficult to evaluate and which can impact the effectiveness of the company in a different way.

- the surplus of internal material resources, the redundancy of information resources and relative resources, in turn, enable taking advantage of identified opportunities.

In this approach it is difficult to evaluate the potential of the organization. Should it be determined by "surplus" or "deficit" factor? Extremely complex but absorbing is a concept of organizational potential in the latter situation. What is relevant here is evaluating the potential business opportunities. This is an original concept as it refers to organizations that develop not through product strategy, markets strategy or business results strategy, but through business opportunities, planning at the most the development of resources. In this case, increasing the resources simultaneously denotes increasing the organizational potential for taking business opportunities. .However, is there any limit of increasing the immaterial resources such as knowledge or relationships, and if so, is there any limit of potential?-this is a complex issue difficult to explain through management theories.

\section{Model of Organization at the Edge of Chaos}

In academic papers concerning the use of Chaos Theory in organizational management it is claimed that balance or proportion between improvisation or entrepreneurship and structured business activity-implied as the edge of chaos-, is a source of maximum business efficiency, especially in turbulent, unpredictable environment, and organizations which reach this state have, as a consequence, relatively strong competitive advantage. This is how S.A Kauffman explains it in his definition (1995) in the context of social organizations, and first of all, 
edge of chaos, proposed by the above mentioned authors, is the most common in the management literature. This model analyses the company's activity in the following six aspects (Brown, Eisenhardt, 1998):

- $\quad$ structured business versus creativity,

- $\quad$ synergies between different aspects of activity,

- past wisdom-innovative business models versus reliance on verified patterns,

- planning-is there a rationale for building up strictly defined business models or should we restrict to determining general direction of company's development?,

- time pace change-describing the pace of change in an organization,

- $\quad$ strategy implementation.

My own proposals concerning the organization operating on the edge of chaos I put forward in the paper entitled Krawędź chaosu jako stan organizacji (Krupski, 2010).

The grounds for building up a model are company's instruments and conflicting business solutions proposed within these instruments. I assumed that pairs of conflicting solutions constitute on the one hand classic business management solutions(characteristic of an organization operating in a strong environment) and on the other hand-business solutions conducive to chaos (characteristic of an organization operating in the turbulent and unpredictable environment). The edge of chaos is determined by features of both the two conflicting solutions.

While making decision about the model tools I eventually resigned from the spectrum of classic management instruments, such as: strategy, organization structure and corporate culture. Maintaining the first one-strategy-for the sake of teleological arguments, instead of the other two I have chosen their more conspicuous designations linked with power in an organization and the sources of organizational effectiveness. I finally completed the specification with the most general aspect of fundamental capability of thinking and reasoning as significant for making any decisions concerning company's organization.

The first tool- thinking and reasoning principle represents the two opposite sides: logic and creativity (as claim the above mentioned authors of Strategy Synthesis.) There exist a spectrum of various modes of thinking and reasoning between them.

Thinking subordinated to logic uses causality. Creative thinking doesn't require any previous assumptions in support (lack of implication), it is of lateral character and it doesn't focus on meaning. The former type fits well in the well acclaimed paradigm, the latter goes beyond and sometimes turns into the origin of a new paradigm. Logical thinking definitely is of a rational character, which leads to disciplined interference. It is also complex (within logic) and coherent. Creative thinking breaks stereotypes, cognitive maps, various routine and conformist
A NEW PERSPECTIVE ON THE POTENTIAL

Rafał Krupski 
A NEW PERSPECTIVE ON THE POTENTIAL

Rafał Krupski behaviours, all that stops generating bold ideas and innovative solutions. (de Witt, Meyer, 2007: 65-66). There are many effective business solutions originating from creative thinking as opposed to solutions resulting from logical thinking. Therefore, looking from the perspective of an undesirable capability of being imitated by the competition, creative thinking is definitely better, nevertheless much more difficult. All practical solutions within the continuum between the extremes should, among others, concern identification of single people(positions) as well as areas (e.g. areas of activity) for which lateral thinking should be an immanent feature. From the formal point of view different solutions between the extremes could be constructed in such a way that logic is used to build up limitations of the desirable creativity. It appears that the edge of chaos is determined here by limitations connected with the survival of the organization rather than domains, objectives and so on.

The second tool, which is the use of power connected with the position one holds in an organization contains two conflicting solutions: managing the organization of a centralized structure including overall co-ordination of all areas of activity and as opposed to it-self-organization. Self-organization is a concept of the Complexity Theory and generally in the most popular CAS systems (Complex Adaptive Systems) it results from the adaptation of different elements of the system to the behaviour of the closest neighbours. This works on a micro scale. On a macro scale however, self-organization results from spontaneous emergence of patterns concerning the whole organization. In other words, work distribution, work coordination and self-control are spontaneous, without managers' interference. This extreme approach is seditious to classical approach of organizational management (what kind of organization is it if there is not any manager?). It appears that in this case, in a context of a given situation, the edge of chaos can be determined by the executives through hierarchical tools, by means of which they can induce managers to support self-organization processes. (Beinhocker, 1999).

The next, third tool - sources of organizational effectiveness - covers synergy and individualism as opposed approaches. How many synergistic effects and how many individualistic ones depends on the context of a given situation, i.e. work complexity, expertise etc. It seems that in companies of innovative sectors, which use electronic and biochemical technologies, the natural direction for searching the edge of chaos is delegating the company's development initiative to individual creators (both in the domain of searching innovative products and services and in the domain of unconventional ways of searching for customers). Comments formulated in this domain, referring to limitations of individualism, are similar to the ones formulated for the first tool. Anyway the borderline of all measures taken in this direction is the risk of company's breakdown.

The fourth tool- principle of business development concerns the following paradox: intended development (included in strategic planning), or opportunity development with restricted planning. Strategic planning devised according to the 
art of strategic planning management, contains in its contents first of all product categories (and closely correlated with them resources), market categories, and categories of financial results. On the opposite pole there is a strategy of exclusive resource categories (mostly immaterial) with a view to using them to take the opportunity. In the latter case, the object of strategic planning is to create conditions necessary to take opportunities. In turbulent, unpredictable environment, market and product planning becomes the object of tactical and operational planning of a term shorter than the one used in strategic planning. Contrary to the previous tools, in which continua between the extreme approaches are purely structured, in order to determine the edge of chaos we can use proposed by me 1/10 degree scale of strategy flexibility (Krupski, Niemczyk, Stańczyk-Hugiet, 2009). According to this scale the last degree-a plan to acquire and develop resources, as the only one within the strategic planning, is the desired edge of chaos.

In Table 1 I presented my own model of management on the edge of chaos believing it is close to the most effective approach for an organization operating in turbulent, unpredictable environment. In considered here aspect of organizational potential, this model can be identified with the model of maximum organizational potential.

The rationale for it is the assumption made that the organization operating on the edge of chaos is the most effective one.

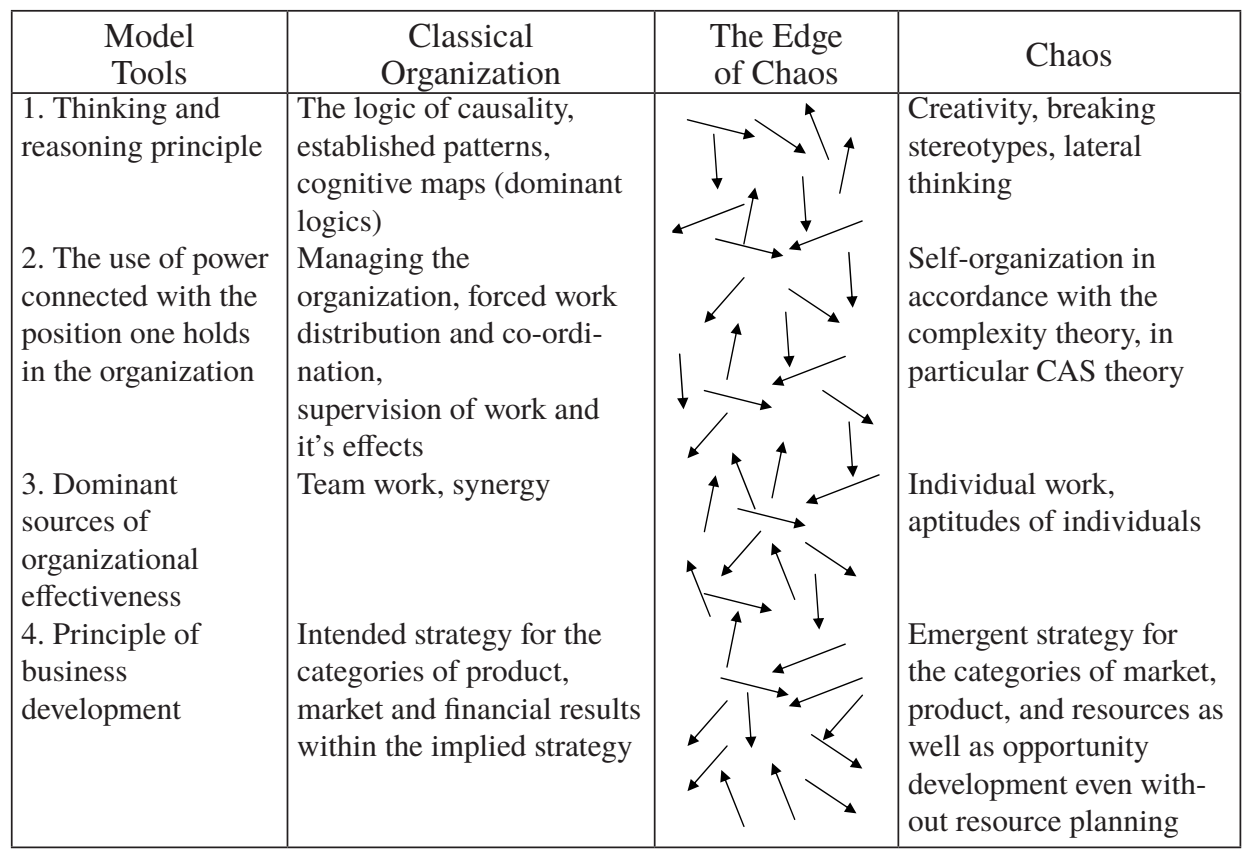

A NEW PERSPECTIVE ON THE POTENTIAL

Rafał Krupski 
A NEW PERSPECTIVE ON THE POTENTIAL

Rafał Krupski

\section{Conclusions}

Searching for the edge of organizational potential is intellectually absorbing, but is it purposeful? Isn't a claim that an organization has still got an operational potential sufficient or a claim that the direction of change has been identified good enough to plan company's development? In some cases these claims are important. In some other, if there are symptoms of untapped potential, ascertaining the scale of discrepancy between the untapped potential and the potential actually used becomes crucial for redefining the strategy of an organization. Searching for the edge of the potential should be a continuous process, or at least it should be reviewed after some time. The scope of the potential of organization's development largely depends on external context and also internal one, which is in a state of flux.

\section{References}

Beinhocker, E. D. (1999), "Robust Adaptive Strategies", Sloan Management Review, Vol. 40, No. 3.

Brown, S.L., Eisenhardt, K.M. (1998), Competing on the Edge: Strategy as Structured Chaos, Harvard Business School Press, Boston, MA.

De Wit, B., Meyer, R. (2007), Synteza strategii, PWE, Warszawa.

Kauffman, S.A. (1995), At Home in the Universe : The Search for Laws of Self-Organization and Complexity, Oxford University Press, New York.

Koźmiński, A.K., Obłój, K. (1989), Zarys teorii równowagi organizacyjnej, PWE, Warszawa.

Krupski, R. (Ed.) (2005), Zarzadzanie przedsiębiorstwem w turbulentnym otoczeniu. Ku superelastycznej organizacji, PWE, Warszawa.

Krupski, R. (2008), „Strategia zbilansowana czy oportunistyczna”, in: Lachiewicz, S., Zakrzewska-Bielawska, A. (Eds.) Teoria i praktyka zarzadzania rozwojem organizacji, Politechnika Łódzka, pp. 28-34.

Krupski, R. (2010), „Krawędź chaosu jako stan organizacji“, in: Rokita, J. (Ed.) Problemy zarzązania organizacjami w warunkach nieprzewidywalności zmian, Górnośląska Wyższa Szkoła Handlowa, Katowice, pp. 21-37.

Lichtarski, J. (2008), „Równowaga i nierównowaga w paradygmatach funkcjonowania i rozwoju przedsiębiorstwa”, in: Krupski, R. (Ed.) Zarzqdzanie strategiczne. Podstawowe problemy WWSZiP, Wałbrzych.

Mały słownik cybernetyczny (1973), WP.

Obłój, K. (2007), „Pułapki teoretyczne zasobowej teorii strategii”, Przegląd Organizacji, No. 5.

Prahalad, C.K., Ramaswamy, V. (2005), Przyszłość konkurencji, PWE, Warszawa 2005.

Stabryła, A., „Analiza elastyczności systemu jako instrument programowania zmian i rozwoju”, in: Rokita, J., Grudzewski, W. (Eds.), Elastyczność organizacji, GWSH, Katowice 2005.

Stankiewicz, M.J. (Ed.) (2010) Pozytywny potencjał organizacji. Wstęp do użytecznej teorii zarzadzania, Dom Organizatora, Toruń, 2010.

Teece, D.J., Pisano, G., Shuen, A. (1997), "Dynamic Capabilities and Strategic Management", Strategic Management Journal, Vol. 36, No. 2. 